\title{
Changes in the Specific Gravity in Rubber Wood Treated with Cashewnut Shell Liquid and Nano Based Wood Preservatives
}

\author{
Mosaraf Hossain $^{1}$, Sandipan Mondal ${ }^{1 *}$, Arnab Banerjee ${ }^{1}$, N. Manju Lekshmi ${ }^{2}$ and \\ B. Manojkumar
}

${ }^{1}$ Kerala University of Fisheries and Ocean Studies, Cochin 682506, Kerala, India

${ }^{2}$ Central Institute of Fisheries Technology, ICAR-CIFT, Cochin-682029, Kerala, India

${ }^{3}$ Kerala University of Fisheries and Ocean Studies, Payyanur Fisheries Station, Kerala, India

*Corresponding author

\section{A B S T R A C T}

\begin{tabular}{|l|}
\hline K e y w o r d s \\
$\begin{array}{l}\text { Nano copper oxide, } \\
\text { Wood preservative, } \\
\text { Rubber wood (Hevea } \\
\text { brasiliensis) }\end{array}$ \\
\hline Article Info \\
\hline $\begin{array}{l}\text { Accepted: } \\
\text { 06 September } 2018 \\
\text { Available Online: } \\
\text { 10 October } 2018\end{array}$ \\
\hline
\end{tabular}

\section{Introduction}

Wood remains the most accepted material for various marine constructional purposes especially the boat building sector due to its versatility. Due to the scarcity of durable wood varieties, fishermen are going to change their focus on non-durable wood varieties. But the problem associated with non-durable wood is its biodegradation. So if proper preservative procedure can be carried out for increasing the self-life of wooden panels. Rubber wood (Hevea brasiliensis) is a low-value, easily available agricultural by-product gaining
Specific gravity (SG) of wood is a measure of the amount of structural material a tree species allocates to support and strength. Specific Gravity of wooden sample is taken by using the ratio of oven-dried weight of the sample to its volume at $12 \%$ moisture content. Rubber wood is a moderately heavy wood which can be used efficiently as a boat building material if proper preservative procedure can be carried out. Due to its refractory behaviour it can easily take up preservative solutions. In this present study Cashewnut ell Liquid and Copper based wood preservative (Nano Copper Oxide) were used. Specific Gravity of different treated wooden panels was carried out. The main objective of the present study is to assess the changes in the specific gravity in the wooden panels treated with different preservative solutions. 


\section{Materials and Methods}

\section{Test samples}

Rubber wood samples were collected from a plantation grown tree for the experiment. Wooden samples of size $120 \times 30 \times 30 \mathrm{~mm}$ were cut and edges were smoothened using a planer.

After that all the panels were air seasoned for a period of four weeks to reduce the moisture content below $15 \%$. Wooden samples should be free from knots and without clear evidence of mould, stains or decay fungi.

\section{Preservative solution and treatment}

Preservatives selected for this experiment was Cashew Nut Shell Liquid (CNSL), Copper oxide ( $>99 \%$ Nano powder) aqueous solution and Colloidal suspension of CNSL with nano $\mathrm{CuO}$. Copper oxide $(\mathrm{CuO})$ solution was prepared by dissolving nano Copper oxide in distilled water $(0.1 \% \quad \mathrm{w} / \mathrm{v})$. Colloidal suspension of CNSL with nano $\mathrm{CuO}$ was prepared in three different concentrations. The concentrations are $0.05 \%, 0.1 \%$ and $0.2 \%$ (w/v) (Table 1).

Preservatives impregnation procedure was carried out by immersion process for getting retention up to a constant level. The retention of the preservative in the panels on wet weight basis was calculated as per ASTM D2481- 81. After preservative treatment of wooden panels air drying was carried out for period of one week.

\section{Calculation of specific gravity}

For calculating Specific Gravity ten samples were selected randomly from each preservative treated wooden panel. These samples were oven dried at $105 \pm 2^{\circ} \mathrm{C}$, weighed and SG was calculated.
Oven dry specific gravity = Oven dry mass/ Oven dry volume/ $\rho$ water

Where, $\rho$ water $=$ density of water, which is $1.000 \mathrm{~g} \cdot \mathrm{cm}-{ }^{3}$ at $4.4{ }^{\circ} \mathrm{C}$

Only oven dry SG is a true specific gravity where mass and volume are determined with wood in the same state.

(Final weight- Initial weight)

Percentage change

In specific gravity $=$ $\times 100$

Initial weight

\section{Results and Discussions}

Wooden samples were treated with different preservatives in different concentration.

After treatment of wooden samples specific gravity was calculated for different treated wooden samples.

Table 2 shows the changes in specific gravity of treated wooden samples along with the percentage change in specific gravity with respect to untreated one.

Figure 1 shows the graphical representation of specific gravity along with Tuckey's post-hoc analysis which explains that control and $0.1 \%$ $\mathrm{CuO}$ treated panels were under the same homogeneity/group with minimum specific gravity and all other treatments were in another group with higher specific gravity.

Maximum value was $0.849 \pm 0.044$ for Colloidal suspension of CNSL with nano $\mathrm{CuO}$ $(0.2 \%)$ and minimum value was $0.644 \pm 0.069$ for wooden panels treated with $0.1 \%$ of nano $\mathrm{CuO}$.

Table 3 shows that there was a highly significant difference in all the treatments with respect to specific gravity. 
Fig.1 Mean \pm SD of specific gravity for treated and untreated rubber wood panels with Tuckey's post hoc analysis

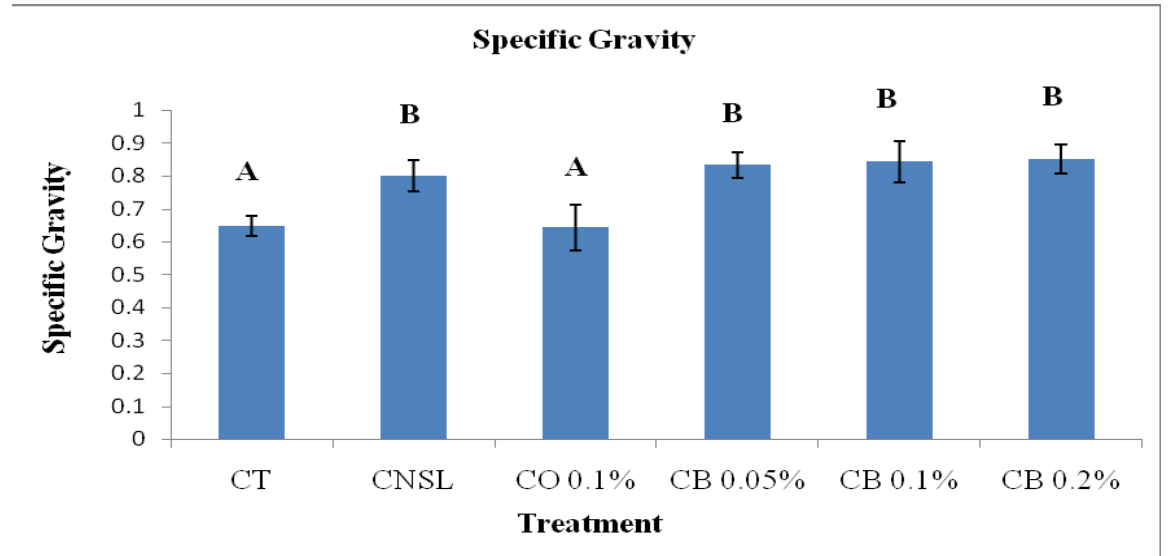

* CT- Control

CNSL- Cashew Nut Shell Liquid

$\mathrm{CO} 0.1 \%-\mathrm{CuO}(0.1 \%)$

CB $0.05 \%$ - Colloidal suspension of CNSL with nano $\mathrm{CuO}(0.05 \%)$

CB $0.1 \%$ - Colloidal suspension of CNSL with nano $\mathrm{CuO}(0.1 \%)$

CB $0.2 \%$ - Colloidal suspension of CNSL with nano $\mathrm{CuO}(0.2 \%)$

Table.1 Different preservatives solutions

\begin{tabular}{|l|}
\hline \multicolumn{1}{|c|}{ Preservative Solution } \\
\hline Only CNSL \\
\hline Only Nano $\mathrm{CuO}$ \\
\hline Colloidal suspension of CNSL with nano $\mathrm{CuO}$ \\
\hline Colloidal suspension of CNSL with nano $\mathrm{CuO}$ \\
\hline Colloidal suspension of CNSL with nano $\mathrm{CuO}$ \\
\hline
\end{tabular}

\begin{tabular}{|c|}
\hline Concentration $(\mathrm{w} / \mathrm{v})$ \\
\hline $100 \%$ \\
\hline $0.1 \%$ \\
\hline $0.05 \%$ \\
\hline $0.1 \%$ \\
\hline $0.2 \%$ \\
\hline
\end{tabular}

Table.2 Mean \pm SD and percentage change in Specific Gravity for treated and untreated rubber wood

\begin{tabular}{l}
\multicolumn{1}{l}{ Treatment } \\
\hline Control \\
\hline CNSL \\
\hline $\mathrm{CuO}(0.1 \%)$ \\
\hline Colloidal suspension of CNSL with nano $\mathrm{CuO}(0.05 \%)$ \\
\hline Colloidal suspension of CNSL with nano $\mathrm{CuO}(0.1 \%)$ \\
\hline Colloidal suspension of CNSL with nano $\mathrm{CuO}(0.2 \%)$ \\
\hline
\end{tabular}

\begin{tabular}{|c|c|}
\hline Specific Gravity (Mean \pm SD) & Percentage Change (\%) \\
\hline $0.648 \pm 0.031$ & $0 \%$ \\
\hline $0.800 \pm 0.048$ & $23.53 \%$ \\
\hline $0.644 \pm 0.069$ & $-0.60 \%$ \\
\hline $0.833 \pm 0.040$ & $28.67 \%$ \\
\hline $0.843 \pm 0.062$ & $30.20 \%$ \\
\hline $0.849 \pm 0.044$ & $31.23 \%$ \\
\hline
\end{tabular}

Table.3 ANOVA table for specific gravity of unexposed untreated and treated rubber wood $(\mathrm{p}<0.05)$

\begin{tabular}{|c|c|c|c|c|}
\hline Source & Sum of Squares & df & Mean Square & $\mathbf{F}$ \\
\hline Treatment & 35.999 & 6 & 6.000 & $2318.850 * *$ \\
\hline Error & .140 & 54 & .003 & \\
\hline R Squared & \multicolumn{4}{|c|}{0.996} \\
\hline
\end{tabular}


At $12 \%$ moisture content, specific gravity of rubber wood was reported as 0.557 (Rubber Board, 2005). In the present study untreated rubber wood panels also showed almost similar specific gravity of 0.648 . According to Williamson and Wiemann (2010) specific gravity was calculated by considering the dry weight of the wood specimen and it was intensely dependent on the weight of wood sample.

Since the weight and specific gravity of specimen were dependent. An increase in weight was observed for CNSL treated wood and a corresponding increase in specific gravity were also noted. Maximum specific gravity $(0.849 \pm 0.044)$ was observed for the panels treated with colloidal suspension of CNSL with nano $\mathrm{CuO}(0.2 \%)$ and lowest $(0.644 \pm 0.069)$ for $0.1 \%$ nano $\mathrm{CuO}$ treated wooden panels.

CNSL is a viscous liquid whose specific gravity is in between 0.95 to 0.97 at $30^{\circ} \mathrm{C}$ (IS 840:1964) hence the retention of CNSL was high and concurrently an increase in the specific gravity. Nano $\mathrm{CuO}$ is corrosive in nature.

So due to Treatment of wooden panels with Nano $\mathrm{CuO}$ there was a loss of structural material of wooden materials as well as decrease in the specific gravity. But in case of Colloidal suspension of CNSL with nano $\mathrm{CuO}$, the effect of nano $\mathrm{CuO}$ is negligible, because the concentration of nano $\mathrm{CuO}$ is less in CNSL.

\section{Acknowledgement}

I wish to thank Director, Central Institute of Fisheries Technology, Kochi; Vice Chancellor, Kerala university of Fisheries and Ocean Studies, Kochi for the opportunity to carry out the work.

\section{References}

Asogwa, E.U., Mokwunye, I.U., Yahaya, L.E. and Ajao, A.A., 2007. Evaluation of cashew nut shell liquid (CNSL) as a potential natural insecticide against termites (soldiers and workers castes). Res J Appl Sci, 2, pp. 939-42.

ASTM (1982) Accelerated evaluation of wood preservatives for marine service by means of small size specimens, D 2481-81, Wood; Adhesives Part-22. American Society for Testing and Materials, Philadelphia, PA.

Board, R., 2005. Rubber growers' companion. Government of India, Kottayam, Kerala, India, 115.

Freeman, M.H. and McIntyre, C.R., 2008. A comprehensive review of copper-based wood preservatives. Forest products journal, 58(11), p.6.

Killmann, W. and Hong, L.T., 2000. Rubber wood: the success of an agricultural byproduct. Unasylva, 51(201), pp. 66-72.

Williamson, G.B. and Wiemann, M.C., 2010. Measuring wood specific gravity correctly. American Journal of Botany, 97(3), pp. 519-524.

\section{How to cite this article:}

Mosaraf Hossain, Sandipan Mondal, Arnab Banerjee, N. Manju Lekshmi and Manojkumar, B. 2018. Changes in the Specific Gravity in Rubber Wood Treated with Cashewnut Shell Liquid and Nano Based Wood Preservatives. Int.J.Curr.Microbiol.App.Sci. 7(10): 720-723. doi: https://doi.org/10.20546/ijcmas.2018.710.079 